\title{
Pufendorf on the Law of Sociality and the Law of Nations
}

\author{
Kari Saastamoinen
}

In his grand exposition of natural law, De jure naturae et gentium (hereafter $J N G),{ }^{1}$ Samuel Pufendorf denied the existence of a separate law of nations as a set of positive legislation agreed by all nations. Following Thomas Hobbes, he maintained that the norms which prevailed between sovereign states were nothing but the application of the law of nature to interstate relations. ${ }^{2}$ The fundamental principle of natural law, in turn, was the duty to cultivate and maintain sociality towards other human beings. ${ }^{3}$ This much about Pufendorf's views can be said without much disagreement among modern commentators. But once we ask what he meant by the endorsement of sociality, among individuals or between states, things become complicated and scholarly opinion diverges. One reason for rival interpretations is that Pufendorf's remarks on the law of nature oscillated between two seemingly incompatible positions. On the one hand, he not only observed that human beings are by nature preoccupied with their personal safety and welfare, but also emphasized that observing natural law serves their long-term interests. With such remarks, he appeared to follow Hobbes in deducing natural law from the requirements of

1 Samuel Pufendorf, De jure naturce et gentium libri octo (Lund: 1672). The modern scholarly edition is De jure naturae et gentium, 2 vols., ed. Frank Böhling, Samuel Pufendorf: Gesammelte Werke, ed. Wilhelm Schmidt-Biggemann, vols. 4.1-2 (Berlin: Akademie Verlag, 1998). This edition identifies the additions Pufendorf made to the expanded edition published in 1684 (JNG 1684). Most of the English translations are from De jure naturae et gentium libri octo, 2 vols., vol. 2: Of the Law of Nature and Nations, transl. C.H. Oldfather and W.A. Oldfather, The Classics of International Law, ed. J.B. Scott, no. 17 (Oxford: Clarendon Press, 1934), hereafter $L N N$. Occasionally, I also use The Political Writings of Samuel Pufendorf, transl. Michael J. Seidler, ed. Craig L. Carr (New York: Oxford University Press, 1994). On Pufendorf, his historical significance and modern Pufendorf scholarship see Michael Seidler, 'Pufendorf's Moral and Political Philosophy,' The Stanford Encyclopedia of Philosophy (Winter 2015 Edition), ed. Edward N. Zalta, https://plato.stanford.edu/archives/win2015/entries/pufendorf-moral/.

$2 J N G$ 1672, book II, chap. 3, § 22 (1684, book II, chap. 3, § 23). LNN, 226.

$3 J N G 1672$, book II, chap. 3 , §15. LNN, 208. 
individual self-preservation. On the other hand, Pufendorf explicitly distanced his method of deducing natural law from that of Hobbes, maintaining that natural law imposes on human beings a reciprocal duty of general friendship, which is not dependent on any consequences for their own security or welfare but relies solely on their shared humanity.

It has been suggested that the discrepancy between these two ways of characterizing natural law is resolved once we realize that only the first mentioned expressed Pufendorf's sincere opinion on the issue. Despite ostensible attempts to distance himself from Hobbes, Pufendorf followed the English philosopher in identifying natural law with principles needed for individual security and welfare. His efforts to dissociate himself from Hobbes on this issue were motivated by a need to avoid the reputation of being a follower of Hobbes, who was widely associated with atheism and amorality in seventeenth-century Europe. This aspiration was especially strong in the expanded edition of $J N G$ published in 1684, as the accusation of being a Hobbist had been one of the charges levelled at Pufendorf after the publication of the first edition in $1672 .{ }^{4}$ Recently, the idea of the Hobbesian character of Pufendorf's theory has also been associated with what is called his international theory. ${ }^{5}$ Pufendorf is

4 The idea of the Hobbesian character of Pufendorf's natural law is defended in great detail in Fiammetta Palladini, Samuel Pufendorf dicepolo di Hobbes: Per una reinterpretazione del giusnaturalismo moderno (Bologna: Il Mulino, 199o). See also Palladini, 'Pufendorf Disciple of Hobbes: The Nature of Man and the State of Nature: The Doctrine of socialitas,' History of European Ideas, 34 (2008): 26-6o. On the debate following the publication of JNG 1672, see Palladini, Discussioni seicentesche su Samuel Pufendorf. Scritti Latini: 1663-170o (Bologna: Il Mulino, 1978). The idea that Pufendorf deduced the content of natural law from the requirements of individual self-preservation is also to be found in Istvan Hont, "The Language of Sociability and Commerce: Samuel Pufendorf and the Theoretical Foundations of the "FourStages" Theory,' in The Language of Political Theory in Early-Modern Europe, ed. Anthony Pagden (Cambridge: Cambridge University Press, 1987), 253, 267; and in Richard Tuck, 'The "Modern" Theory of Natural Law,' in The Languages of Political Theory in Early-Modern Europe, ed. Anthony Pagden (Cambridge: Cambridge University Press, 1987), 105. Tuck has later modified his position, seeing now a marked difference between Hobbes and Pufendorf on this issue. Richard Tuck, The Rights of War and Peace. Political Thought and the International Order from Grotius to Kant (Oxford: Oxford University Press, 1999), 151-152. See also Ian Hunter, 'Natural Law as Political Philosophy', in The Oxford Handbook of Philosophy in Early Modern Europe, ed. Desmond Clarke and Catherine Wilson (Oxford: Oxford University Press, 2011), 490.

5 Theodore Christov, Before Anarchy. Hobbes and His Critics in Modern International Thought (New York: Cambridge University Press, 2015). Other recent writings exploring Pufendorf from the perspective of international relations are Peter Schröder, Trust in Early Modern International Political Thought, 1598-1713 (Cambridge: Cambridge University Press, 2017), Ben Holland, The Moral Person of the State. Pufendorf. Sovereignty, and Composite Polities (Cambridge: Cambridge University Press, 2017), and Vanda Fiorillo, 'States, as Ethico-Political 
presented as a closet Hobbesian who used the vocabulary of sociality to camouflage the similarities between his and Hobbes's conclusions. Behind his 'selfprofessed anti-Hobbesian sentiments', Pufendorf implicitly acknowledged the 'authentically Hobbesian foundations in the construction of the international political order' 6

The idea of the close affinity between Hobbes's and Pufendorf's accounts of natural law has obvious merits. Above all, it has made obsolete the previously widely shared view of Pufendorf as Hobbes's adversary, who rejected the latter's gloomy picture of human nature and established natural law on the idea of a natural human inclination to sociability, inspired by Hugo Grotius. While Pufendorf heralded Grotius as his most important predecessor in the study of natural law, it has been shown convincingly that the single most significant intellectual inspiration behind his theory was Hobbes. Pufendorf found no natural inclination to peaceful sociality in human nature, as he saw human behaviour governed mainly by self-love and self-preservation, and often also by an inclination to hurt others. The cultivation of sociality was a norm imposed on such creatures with the purpose of advancing peaceful social life. The Hobbesian inspiration was even more obvious in Pufendorf's theories of the state of nature and civil society. It also seems plausible that Pufendorf wanted to avoid the reputation of being a Hobbesian, and some of the things he wrote to that end may well have been the original source for his fame as an adversary of Hobbes. ${ }^{7}$

Nevertheless, nothing in the above forces us to conclude that Pufendorf followed Hobbes in deducing natural law from the requirements of individual selfpreservation. And in this chapter, I will argue that there are good reasons for holding that he did not. While Pufendorf shared Hobbes's view of the pivotal role self-preservation and self-love play in human behaviour, his idea of natural law differed significantly from that of the English philosopher. This disagreement between Hobbes and Pufendorf was most visible in their rival views on the character and status natural law has outside civil society, and it indicated noteworthy differences in the ways they articulated the moral relations between sovereign states. In the first part of this chapter, I will explore how Pufendorf

Subjects of International Law: The Relationship between Theory and Practice in the International Politics of Samuel Pufendorf,' in System, Order, and International Law: The Early History of International Legal Thought from Machiavelli to Hegel, ed. Stefan Kadelbach, Thomas Kleinlein, and David Roth-Isigkeit (Oxford: Oxford University Press, 2017), 199-215. These works came out too late to be commented on here.

6 Christov, Before Anarchy, 143-157, 176.

7 Palladini, 'Pufendorf Disciple of Hobbes,' 59-6o. 
deduced the cultivation of sociality as the fundamental principle of natural law. ${ }^{8}$ In the second part, I will analyse his remarks on Hobbes's theory and show how their different methods of deducing natural law were connected to their dissimilar understanding of interstate relations. In doing this, I will distinguish between what Pufentorf wrote in the first edition of $J N G$ (JNG 1672) and what he added to the edition of 1684 (JNG 1684). While the numerous new references to classic Stoic texts and Richard Cumberland's anti-Hobbesian De legibus naturae (1672) may well have served the purpose of defending the author from the charges of being a Hobbesian, many of the remarks Pufendorf added to JNG 1684 were fully in line with the theory he had put forward in $J N G 1672$.

\section{Sociality as the Fundamental Principle of Natural Law}

The first thing to explore here is the demonstrative science of natural law. For Pufendorf, reflecting on natural law and sociality was not a matter of adopting some true philosophical doctrine. There were many argumentative strategies to convince people of their need to ponder morality and social institutions from the perspective of sociality. ${ }^{9}$ One could try to convince them that it serves their personal interests to do so, or one could use suitable citations from philosophers of different schools to show how wise men have reached similar conclusions despite their dissimilar intellectual starting points. In JNG Pufendorf used both approaches, but he also found it important to argue that there was a demonstrative science of natural law. By 'demonstrative science' he did not refer to a process of inquiry but to a certain type of organized knowledge. The model for such knowledge was not Euclidian geometry, which had inspired his early Elementorum jurisprudentiae universalis (1660), but the Aristotelian demonstrative syllogism. Demonstrative science consists of evident propositions and propositions which can be reduced back to such obvious statements, and it offers knowledge about necessary connections between things. In this way, it is 'certain and clear' as well as valid 'everywhere and at all times.'10

8 In this part I will reformulate and further develop ideas presented in Kari Saastamoinen, The Morality of the Fallen Man. Samuel Pufendorf on Natural Law (Helsinki: Finnish Historical Society, 1995).

9 This much, at least, I agree with Knud Haakonssen, 'Rejoinder to My Commentators,' in 'Pufendorf on Power and Liberty', in the series Liberty Matters: A Forum for the Discussion of Matters pertaining to Liberty (January 2017). http://oll.libertyfund.org/pages/lm-pufendorf. $J N G$ 1672, book I, chap. 2, § 3. LNN, 23-24. On Pufendorf's moral science, see Saastamoinen, The Morality of the Fallen Man, 54-62. 
In Pufendorf's view, it was an error to think, as most scholars had done, that demonstrative certainty is impossible in moral sciences. ${ }^{11}$ This did not mean, however, that the quest for certainty was a central concern of his enterprise. Human beings adopt their moral views unreflectively from education and prevailing social practices, and most of them lack the capacity to understand how natural law follows from first principles. ${ }^{12}$ Their knowledge of natural law is always probable in character, and Pufendorf saw no need for things to be otherwise. His criticism of the view that moral sciences lack demonstrative certainty was not that this had left humankind in a state of moral scepticism. What he complained about was that it 'has worked an immense injury' to moral science, as it has 'caused scholars to investigate but diffidently into that which they believed rested on so slippery a foundation'. To those scholars who have altogether neglected the moral sciences, it has offered 'the plausible excuse, that they were founded on no certain demonstrations, and could be treated merely in a rough and ready fashion.'13

Achieving full certainty was less important than exploring natural law in a thorough manner and having a clear understanding of its character and purpose. Such an intellectual exercise was the job of intelligent and well-educated experts and persons in important governmental positions, and it was these people Pufendorf addressed in $J N G$. It is important to note that his demonstrative account of natural law did not aim to describe or transform the moral selfunderstanding of the uneducated common people, who observed natural law by following the general example of society, without comprehending how its precepts could be demonstrated. ${ }^{14}$ In the case of the common people, it was the duty of the sovereign to take care that they follow laws not so much due to their fear of punishment than out of habit. ${ }^{15}$ To be sure, even those with mediocre intelligence could understand the demonstration of natural law, if this was presented to them by others. ${ }^{16}$ Yet, Pufendorf made it clear that his compendium of natural law for university students, De officio hominis et civis (hereafter $\mathrm{OHC}$ ), offered only the rudiments of the demonstrative understanding of natural law. ${ }^{17}$ In the preface to this work he explained how it is 'in the public interest to steep

\footnotetext{
$11 J N G$ 1672, book I, chap. 2, § 1. LNN, 22.

$12 J N G$ 1672, book I, chap. 3, § 5; book II, chap. 3, § 13. LNN, 42, 2O2-2O3.

$13 J N G 1672$, book I, chap. 2, § 1. LNN, 22.

$14 J N G$ 1672, book II, chap. 3, § 13. LNN, 2O2-203.

$15 J N G$ 1672, book VII, chap. 9, § 4. $L N N$, 1119. On Pufendorf's views on habitual behaviour, see Heikki Haara, Sociability in Samuel Pufendorf's Natural Law Theory (PhD diss., University of Helsinki, 2017), 27-36.

$16 J N G$ 1672, book II, chap. 3, § 13. LNN, 202.

17 Samuel Pufendorf, De officio hominis et civis juxta legem naturalem libri duo (Lund: 1673). The modern scholarly edition is De Officio, ed. Gerald Hartung, Samuel
} 
in the minds of young men a moral doctrine whose usefulness in civil life is accepted as obvious'. But to achieve this aim one should take care that students are not 'put off at the beginning by a massive accumulation of difficult questions', which would happen if they were 'to set out on the wide expanses of this subject without a knowledge of what one might call the elements.' ${ }^{18}$ Thus, the idea of demonstrative moral science was unmentioned in $\mathrm{OHC}$, and the argumentation in this work was often considerably looser than in JNG. This should not, however, be understood to mean that Pufendorf regarded the idea of demonstrative moral science as insignificant. After all, what was equally missing in $O H C$ was one of his main claims to fame: the theory of moral entities. ${ }^{19}$

The important point in this context is that when Pufendorf defended the possibility of demonstrative moral knowledge, he made a distinction between two fields of moral sciences. One of them, associated by Pufendorf with prudence, is concerned with 'the successful management of one's own actions and those of others, with an eye to the security and welfare primarily of the public'. ${ }^{20}$ This kind of reasoning cannot achieve demonstrative certainty, as it is founded on 'axioms drawn by a dexterous observation and collection of the customs of men and the events of human history', and because 'the smallest things can change radically the outcome in human affairs'.21 The other field of moral science deals with norms which determine the rectitude of human actions, and this is by and large identical with the science of natural law. Pufendorf explained that why this kind of moral knowledge can be demonstrative would become fully apparent later in the work, when he explores the origins of natural law. ${ }^{22}$ This indicated that the demonstrative character of such knowledge has to do with premises which are founded on the contemplation of 'man's nature, condition and inclinations'.23 Pufendorf added that while our actions are free, and therefore not necessary, once some principles have been imposed on them, this gives rise to 'affections', which can be demonstrated. ${ }^{24}$ In $J N G 1684$ he clarified this remark by explaining that 'the acts which fall under the conduct of the law of nature have an intrinsic force toward sociality'

Pufendorf: Gesammelte Werke, ed. Wilhelm Schmidt-Biggemann, vol. 2 (Berlin: Akademie Verlag, 1997). OHC, Prefatio. The English translation is from On the Duty of Man Citizen, ed. James Tully, transl. Michael Silverthorne (Cambridge: Cambridge University Press, 1991), 6.

19 On moral entities, see $J N G$ 1672, book I, chap. 1.

$20 J N G 1672$, book I, chap. 2 , § 4. $L N N, 24$.

$21 J N G$ 1672, book I, chap. 2, § 4. $L N N, 25$.

$22 J N G$ 1672, book I, chap. 2, § 5. LNN, 26.

$23 J N G$ 1672, book II, chap. 3, § 14. LNN, 205.

$24 J N G$ 1672, book I, chap. 2, § 5. LNN, 26. 
(socialitas). ${ }^{25}$ While these acts are contingent in the sense that they follow from our free decisions, the relationship between these acts and their effects on sociality 'is necessary and natural, and therefore capable of demonstration.' ${ }^{26}$ Below we will see how Pufendorf referred, already in JNG 1672, to this idea in his definition of the fundamental principle.

Natural law has to do with acts which have a necessary effect on sociality among human beings. To be sure, Pufendorf made it clear that there is also a strong positive correlation between the observance of natural law and the promotion of one's personal salus, a term which referred to both physical security and welfare. This is a theme Pufendorf emphasized especially in JNG 1684. All in all, actions which are in accordance with the rules of sociality not only 'maintain and increase a man's standing, reputation, and position', but also 'procure some advantage and reward for a man, and contribute to his happiness'. Actions repugnant to these rules, in turn, 'may at times return some utility, and more often some pleasure, which however never endures for long, and is followed by a throng of much greater ills. ${ }^{27}$ However, in the paragraph on the sanctions of natural law added to JNG 1684 Pufendorf gave a more nuanced picture of the issue. There, he admitted that those are not totally mistaken who claim that 'many are returned for their benefactions only hatred, envy, and other ills, while, on the other hand, others enjoy without punishment the fruits of their evil deeds'. Accordingly, Pufendorf qualified his position by pointing out that, while 'it cannot be assumed, without chance of error, that for our good deeds we shall be returned in kind by other men', still 'it is sure that, from good actions, we can reasonably hope for advantages with a degree of certainty that would not be justified if one were to expect to get them from opposed vices'. While the consequences of our morally good deeds are never certain, there 'is still an evident probability that not a few benefits will follow, or at all events more than what can be expected from evil actions.' ${ }^{28}$

In other words, while actions ordered or forbidden by natural law have a necessary effect on sociality, their effects on our personal safety and welfare are never more than highly probable. For example, a person who steals a large sum of money evidently violates natural law. And while the likeliest scenario is that this person will be severely punished, it is not impossible that he or she

$25 J N G$ 1684, book I, chap. 2, § 5: 'Sane enim constat, actus, de quibus naturali lege disponitur, intrinsecam habere vim ad socialitatem'. Translation K.S.

26 Ibid. '[N]exus inter actus nostros \& effectus omnes independentes necessarius est, \& plane naturalis, eoque demostrationis capax'. $L N N, 26$.

27 JNG 1684, book II, chap. 3, § 10. LNN, 196.

$28 J N G$ 1684, book II, chap. 3 , § 21. LNN, 223. 
will not get caught, but end up being a rich and respected member of society. Such uncertainty concerning the effects of our actions does not characterize the consequences stealing money has for sociality. Human beings cannot but be grossly aggravated when someone takes their property without their permission, wherefore theft has always a negative effect on sociality. ${ }^{29}$ This would suggest that, in Pufendorf's theory, the duty to cultivate sociality is not merely a means to promote one's own security and welfare. While human beings have strong innate inclination to preserve their own lives and to promote their personal welfare, their most fundamental moral duty is to behave in a manner which promotes sociality among human beings.

There are several features in $J N G$ which support this interpretation. The first thing to note is the role Pufendorf gave to God in defining the content of the fundamental principle. It is well known that he saw the morally obligating character of natural law as being dependent on the idea that it is imposed by God. ${ }^{30}$ However, the idea of God was explicitly present also throughout his discussion of the content of the fundamental principle. While Pufendorf saw human reason as unable to understand the true character of God, this did not prevent him from holding that reason can make it possible to draw some conclusions about God's intentions in creating the human species. Already in the chapter on the moral entities he declared that the first moral entities were imposed on human beings by God, who did not want human beings to live 'without being accountable to any law, rule, or necessity' but wanted 'men's life and actions to be tempered by certain principles. ${ }^{31}$ More importantly, Pufendorf started the discussion of natural law in JNG Book II by asking how, since God has given human beings a free will, do we know for sure that God had not granted them a full liberty to follow their own will but wants them to observe a law. ${ }^{32} \mathrm{His}$ answer was that we know this from the fact that full liberty would be disadvantageous and prejudicial to human nature, and that the salus of human nature requires it to be restricted by law. ${ }^{33}$ While God has given other animal species a sort of liberty to follow their own desires, the fact that they had not been endowed with a soul capable of recognizing a law makes it apparent that God was pleased to manifest his power simply by creating and destroying them. ${ }^{34}$ In the case of human beings, the fact that God has endowed them with

\footnotetext{
$29 J N G$ 1672, book III, chap. 1, § 1. LNN, 314.

$30 \quad J N G$ 1672, book I, chap. 2, § 6; book II, chap. 19-20. LNN, 27-28, 215-218.

$31 J N G$ 1672, book I, chap. $1, \S 3 . L N N, 5$.

$32 J N G$ 1672, book II, chap. $1, \S 1 . L N N, 145$.

$33 J N G 1672$, book II, chap. $1, \S 2 . L N N, 145$.

$34 J N G$ 1672, book II, chap. 1, § 4. LNN, 148.
} 
intellectual and moral capabilities indicate that God wanted them to establish an organized way of living, and by doing so increase God's glory and their own happiness. ${ }^{35}$ Moreover, the inability of human individuals to survive without the company and assistance of other members of their species means that a social way of living is necessary for the salus of human beings. Yet, the strong human proclivity to hurt one another and the great variety of their inclinations indicate that social life is impossible without law. Thus, Pufendorf closed the discussion by concluding that the idea of the natural liberty of human beings should always be understood as 'something restrained by sane reason and natural law'. ${ }^{36}$

The above indicates clearly and explicitly that God is concerned with the salus of human beings, and that this is the aim for which he has imposed natural law on them. This was the most elementary assumption in Pufendorf's deduction of the fundamental principle. It was also an idea which, he thought, most of his readers were ready to accept, irrespective of their religious confession and without further evidence or argument. Equally obvious was that God has imposed natural law on the human species collectively. This idea may sometimes be blurred by the fact that Pufendorf used, in the conventional manner, the singular form, homo, as a generic term to indicate both the whole human species and human individuals as representatives of the species. Thus, he spoke interchangeably about the salus of a human being, the salus of human nature and the salus of the human species. ${ }^{37} \mathrm{He}$ also explained how after God had made a human being (homo) an animal who could not be salvum unless he observed natural law, one could not believe that God would annul or change natural law without changing human nature. ${ }^{38}$ In this statement homo did not refer to the members of the human species individually, as Pufendorf knew well that there are people who prosper even though they have violated natural law. It signified the whole human species, which cannot survive unless a significant majority of its members observe natural law at least most of the time. Of course, Pufendorf did not hold that the preservation and welfare of the human species could be separated from the salus of its individual members. But this was something he presented, already in 1672 , as a corollary of the duty to cultivate sociality. The sociality for which God has created human beings 'cannot be exercised and preserved to good advantage unless every man improves and preserves himself to the best of his ability'. Thus, 'when a man

$35 J N G$ 1672, book II, chap. $1, \S 5 \cdot L N N, 149$.

$36 \quad J N G$ 1672, book II, chap. 1, § 6-8. LNN, 149-153.

37 JNG 1672, book II, chap. 1, § 2; book II, chap. 3, § 11, § 15. LNN, 145, 199, 208.

$38 J N G 1672$, book II, chap. 3 , § 5. LNN, 185 . 
neglects his own care, he works an injury, not, indeed, on himself, but on God, his Creator, and on the human race. ${ }^{39}$ In $J N G ~ 1684$ Pufendorf encapsulated this idea in the remark that 'the safety [salus] of the whole of human society is an unintelligible phrase, if it makes no difference whether individuals are safe [salvum] or not: 40

How, then, do we know that God has imposed the duty to cultivate sociality on the human species? The mere fact that God wants humankind to survive and prosper does not tell us what norms human beings should obey to achieve this end. At the beginning of the chapter 'On the law of nature in general', Pufendorf explained that, after showing how the condition God has imposed on human beings does not permit them to live without law, he would now explore the most general norm human beings are obligated to follow. ${ }^{41}$ After commenting on some previously presented ideas about natural law, he did this in much-cited paragraphs II.3.14-15.

It should be clear by now that, when Pufendorf at the beginning of paragraph II.3.14 declared that 'there is no more direct and appropriate way to investigate natural law than to contemplate carefully man's nature, condition, and inclinations', this did not indicate a fresh start out of nothing. Pufendorf took it for granted that the general end of natural law, the salus of the human species, was clear for every attentive reader. And since these readers understood that human salus consists of both preservation and welfare, he could say, before making a single observation concerning the human condition, that whether this law is imposed by God 'to advance man's happiness or to restrain his evil dispositions, which may be to his own destruction, there is no easier way to learn it than by observing when man needs assistance and when he needs restraint'42 Thus, when Pufendorf started his contemplation on the human condition by referring to the tendency of human beings to love themselves more than others, and to protect their own lives by all possible means, he was not declaring that in these inclinations we have found the true end of natural law: individual preservation and welfare. ${ }^{43}$ Pufendorf's point was that in determining the most general norm needed for the salus of the human

$39 J N G$ 1672, book II, chap. 4, § 1 (1684, book II, chap. 4, § 16). LNN, 256.

$40 \quad J N G$ 1684, book II, chap. 4, § 16. LNN, 256.

$41 J N G$ 1672, book II, chap. 3 , § 1. LNN, 179.

$42 J N G$ 1672, book II, chap. 3, § 14. LNN, 205.

43 Later in $J N G$ Pufendorf made it clear that the mere fact that the human nature is endowed with an affect or an inclination does not indicate that this is how natural law wants human beings to behave, as most of such natural tendencies are evidently opposed to natural law. JNG 1672, book VI, chap. 1, § 28. $L N N, 891$. 
species one could not rely on any human tendency to altruism or self-sacrifice. Instead, one had to take seriously the fact that human beings are usually ready to give assistance to others only if they think that it is in their own interest to do so, and that they are bound to behave aggressively towards anyone they see as a threat to their own security. The other relevant features for identifying the fundamental norm were the inability of human beings to survive without other people's assistance, their extensive ability to help each other, and their strong tendency to inflict harm on one another. ${ }^{44}$

After these observations, Pufendorf was ready to deduce the most general norm for the salus of the human species. His argument had an empirical and a normative component. The empirical component goes as follows.

Man [homo], it is clearly apparent, is an animal most eager to preserve himself, essentially in need, ill-equipped to maintain himself without the aid of those who are like him, and very well suited for the mutual promotion of advantages. All the same, he is often malicious, insolent, easily annoyed, and both ready and able to inflict harm. For this kind of animal to be safe [ut salvum sit], it is necessary that he be sociable. That is, he must will to be so united with those who are similar to himself and conduct himself towards them in such a way that they are provided with no cause to hurt him but instead have a reason to maintain or promote his advantage. ${ }^{45}$

Here, homo is a generic term referring to the human species, and the statement expresses the most general requirement for the preservation and welfare of this species and its individual members: their reciprocal willingness to join together in the purpose of exchanging services, and their need to behave in a manner which mutually motivates such activity. From this observation Pufendorf made the following normative conclusion.

And so the fundamental law of nature will be this: Every man must, inasmuch as he can, cultivate and maintain towards others peaceful sociality. A corollary of this is that, since whoever obligates a man to an end obligates him as well to the means without which the end cannot be obtained. All things which necessarily work to that sociality [ad istam socialitatem

$44 J N G$ 1672, book II, chap. 3 , § 14. LNN, 207.

$45 J N G$ 1672, book II, chap. 3 , § 15. LNN, 207-208. The English translation is from The Political Writings of Samuel Pufendorf, 151-152, excluding a remark Pufendorf added to JNG 1684. 
necessario faciunt] are understood to be commanded by natural law, and all that disturb or destroy it to be forbidden. ${ }^{46}$

There are two things to note here. First, following the views he had presented in the chapter on the certainty of moral science, Pufendorf maintained that the laws of nature command or forbid acts which have a necessary effect on sociality among human beings. Accordingly, his demonstrations of the most general individual precepts of natural law relied very much on their status as necessary means for preventing violence and discord among human beings. ${ }^{47}$ Second, since the end of natural law is the salus of the whole humankind, it obligates human beings to cultivate sociality also in their relations with individuals who are not able to help or hurt them, including a human foetus, who completely lacks such capabilities. ${ }^{48}$ It should be noted that the above citation is from JNG 1672. In JNG 1684 the argument was interrupted by a long remark on the character of sociality. As a result, the reference to the necessary effects that acts observing or violating natural law have on sociality is often left unmentioned by modern commentators.

It has been argued that Pufendorf's fundamental principle of natural law was actually a reformulation of the first principle of natural law Hobbes had defined in De cive as the duty 'to seek peace when it can be had; when it cannot, to look for aid of war' ${ }^{9} 9$ However, Hobbes's first principle relied entirely on his idea of natural law as 'the Dictate of right reason about what should be done or not done for the longest possible preservation of life and limb: ${ }^{50}$ Nothing like this was ever suggested or even tacitly assumed by Pufendorf. For him, the principle behind the fundamental principle was the idea of natural law as a norm God had imposed to foster the salus of the human species. Accordingly,

46 Ibid. English translation by K.S., following The Political Writings of Samuel Pufendorf, 152, and $L N N, 208$, and excluding the additions made to JNG 1684 .

47 For an example of such argumentation, see Kari Saastamoinen, 'Pufendorf on Natural Equality, Human Dignity, and Self-Esteem,' Journal of the History of Ideas 1 (2010): 39-62.

48 Pufendorf held that all human beings share a right of not being hurt by others, and this also applies to an embryo in the womb of her mother. JNG 1672, book I, chap. 1, § 7 . $L N N$, 8. On the natural law and rights in Pufendorf's theory, see Kari Saastamoinen, 'Liberty and Natural Rights in Pufendorf's Natural Law Theory', in Transformations in Medieval and Early-Modern Rights Discourse, ed. Virpi Mäkinen and Petter Korkman (Dordrecht: Springer, 2006), 225-255.

49 Thomas Hobbes, De cive (Amsterdam, 1647, 2nd ed.), chap. II, § 2. The translation is from On the Citizen, ed. Richard Tuck, transl. Michael Silverthorne (Cambridge: Cambridge University Press. 1998), 34. Palladini, 'Pufendorf disciple of Hobbes,' 5 o. See also Hunter, 'Natural Law as Political Philosophy,' 490. 
he established the obligation to preserve one's own life and the right to protect it by violent means by arguing that the non-existence of such norms would have negative effects on sociality. The argument for the first mentioned duty was, as we saw above, that sociality cannot be exercised and properly preserved 'unless every man improves and preserves himself to the best of his ability'. ${ }^{51}$ In the case of violent self-defence, Pufendorf found it meaningful to remark that when we kill or injure someone to protect our own lives, we do this to a human being 'with whom we are required to cultivate social life, while by his death apparently as great a loss is entailed upon the human race as would come from our own death'. The reason why this observation should not prevent us from defending ourselves against an unjustified attack is that if natural law denied good people the right to protect themselves against the bad ones, this would not advance the salus of the human species. On the contrary, it would indicate 'the end of mankind'. ${ }^{2}$ It is important to bear in mind that with such arguments Pufendorf was not describing the mental process by which human beings adopt their moral beliefs. Human beings internalize their moral convictions through education and daily social practice, though the above norms happen to find extra motivational strength in self-love and the inclination to self-preservation. What Pufendorf was explaining was how natural law norms follow from the first principles, and he did this for a small minority, whose task it was to understand properly the character and purpose of natural law.

The above method of deducing natural law makes it understandable why Pufendorf felt there was a need to explain how his theory compared with that of Hobbes. As he maintained that self-love and self-preservation have a predominant role in human behaviour, it was inevitable that he was going to be associated with Hobbes by his contemporaries. And his Hobbes-inspired ideas of the state of nature and the origins of civil society were only going to make this connection stronger. Thus, right after deducing the fundamental principle, Pufendorf used three paragraphs to compare his position with the one Hobbes had put forward in De cive. There is no reason to conclude that he did this to camouflage the true Hobbesian character of his natural law. Once we take seriously the idea that the fundamental duty of natural law is to cultivate sociality,

\footnotetext{
$51 J N G$ 1672, book II, chap. 4, § 1 (1684, II.4.16). LNN, 256.

$5^{2} J N G$ 1672, book II, chap. 5, § 1. LNN, 264-265.
} 
not to preserve one's own life, it becomes apparent that Pufendorf had good reasons to distinguish his own theory from Hobbes's 'cleaver' method of deducing natural law 'solely from the care of one's own safety'.53

Pufendorf admitted that Hobbes's method had the virtue of establishing clearly how important it is for the welfare of human beings that they follow such dictates of reason. After all, Hobbes had not claimed that each person should 'seek his own advantage to the detriment of others', but had, rather, observed how 'care of our own welfare itself orders us to observe the laws of sociality, since our welfare cannot remain secure without this. ${ }^{54}$ This was no small merit, as Pufendorf valued all arguments which could be used to convince people that observing natural law serves their personal interests. Nonetheless, as a demonstration of natural law Hobbes's method was unsatisfactory. The mere fact that some rules are beneficial for one's personal salus fails to indicate 'that a man has right to apply them as means toward his own preservation' and that he is 'bound to observe them as by some law'. To 'receive the force of law', these dictates of reason must be deduced from a different principle. ${ }^{55}$ This could, of course, be understood to mean that in order to be proper laws, these precepts should be seen as God's commands. However, Pufendorf knew well that Hobbes had said the same thing in De cive, so there was no need to criticize Hobbes over this issue. ${ }^{56}$ And when Pufendorf himself made the point about God's role, he wrote that for the rules of sociality to be proper laws, 'a higher principle is needed' (sublimior principio opus est). ${ }^{57}$ In the case of Hobbes's method of deducing natural law, however, a higher principle was not enough. The law of nature had to be deduced from an altogether different principle (omnino ex alio principio deducendum est). ${ }^{58}$

This entirely different principle was the duty to promote sociality, and it relied on the idea of natural law as a norm God has imposed to promote the salus of the human species. This was clearly assumed when Pufendorf commented on Hobbes's infamous remark that if 'man naturally loved his fellow man', it would be difficult to understand 'why everyone would not love everyone equally as equally men, or why every man would rather seek the company of men whose society is more prestigious and useful to him than to others. ${ }^{59}$

$53 J N G$ 1672, book II, chap. 3, § 16. The Political Writings of Samuel Pufendorf, 153.

$54 J N G$ 1672, book II, chap. 3, § 16. LNN, 211.

55 Ibid.

$56 J N G$ 1672, book II, chap. 3 , $20 . L N N, 219$.

57 Ibid. $L N N, 217$.

$5^{8} J N G$ 1672, book II, chap. 3, § 16. LNN, 211.

59 De cive, chap. I, § 2. On the Citizen, 22. 
In his comment, Pufendorf identified the general love of other human beings with the duty to cultivate sociality, arguing that Hobbes had confused the most general duties of sociality toward all human beings with the motives human beings have when they establish particular societies. For 'reasons cited above', i.e. in the deduction of the fundamental principle, natural law has ordained a duty of general friendship (amicitia) among all human beings, excepting only those whose monstrous deeds had excluded them from the human moral community. This duty of friendship is not dependent on the ability of the other person to help or hurt us, but solely on the fact that he or she is a human being. ${ }^{60}$ It consists of abstaining from violating other people's life and property, holding them as one's moral equals by nature, and observing what Pufendorf called the duties of humanity. Such a friendship is not contradicted by the fact that people seek closer company and make special agreements with those from whom they expect honour or benefits. The end of natural law is the salus of the human species, and it obligates every one of us to take care of ourselves. Therefore, sociality should be cultivated so 'that by mutual exchange among many of assistance and property, we may be enabled to take care of our own concerns to greater advantage. ${ }^{61}$

Hobbes's and Pufendorf's different methods of deducing natural law were connected to a dissimilar understanding of the character this law has outside civil society. In his political theory, Hobbes had maintained that the most elementary requirement for preserving one's own life was peace, and he had identified several laws of nature which human beings needed to observe in order to maintain peace. These laws were, Hobbes declared, 'immutable and eternal' rules of human morality. ${ }^{62}$ However, it was rational to believe that observing these precepts would preserve one's safety only when there were good reasons to assume that others would do the same. Such situations were not impossible outside civil society, but they were limited in scope and usually did not last long. When such circumstances did not prevail, the laws of nature obligated human beings only in 'the internal court' (in Foro interno), meaning that they had a duty to seek a situation in which observing them would become rational. As long as such a situation did not exist, the duty to preserve one's own life ordered them to use all possible means, including war, to protect their own lives. ${ }^{63}$ Since there were no relations of authority among people in the state of nature, it was up to each individual to decide 'whether the means he is to use

6o JNG 1672, book II, chap. 3, § 16. LNN, 212.

$61 J N G$ 1672, book II, chap. 3, § 18. LNN, 214.

62 De cive, chap. III, § 29. On the Citizen, 54.

63 De cive, chap. III, § 27. On the Citizen, 53-54. 
and the action he intends to take are necessary to the preservation of his life and limbs or not'.64 And Hobbes claimed that in relation to other human beings this meant that 'every man was permitted to do anything to anybody, and to possess, use and enjoy whatever he wanted and could get'. In other words, everyone had 'a right to all things'. ${ }^{5}$

Pufendorf was acutely aware of the above elements in Hobbes's theory, so much so that he seems to have thought they were bound to give a scholar using Hobbes's idea a bad reputation. Thus, when he commented on them in the chapter on the state of nature, he was less interested in criticizing Hobbes than in suggesting that Hobbes had not meant what he had written. While Hobbes's remarks appeared 'paradoxical at the first sight', actually he had not denied that there are objective rules of self-preservation already in the state of nature. After all, the idea that a human being would have a 'licence to do whatever he pleases to anyone he pleases' could not be 'considered by any sane man a sufficient means for his continued preservation'. Thus, it 'must be concluded that nature never has granted it'. The real meaning of Hobbes's remarks must be, first, that natural law has initially given human beings a right to use those material things they need for their preservation, though later these had been divided by agreements, and second, that he who has no superior can use his own will, when guided by right reason, to do 'whatever will work for his continued preservation'.66 Pufendorf returned to Hobbes's views when he discussed the reasons for establishing civil society, offering again a similarly favourable interpretation. Hobbes's idea of 'the right against all men and to all things' should not be extended further 'than sane reason admits'. It indicates merely that a person 'has a right to use all the means, which right reason judges necessary for his preservation, against all by whom the same right reason suggests that he is threatened'. The answer to the question of when a person is so much menaced by someone else that this allows a violent reaction is not a matter of purely subjective reasoning, but something for which there are intersubjective criteria of right reason. ${ }^{67}$

It has been suggested that with the above remarks Pufendorf was correcting Hobbes's theory by using a remark Hobbes himself had made about right reason and natural law in a note he added to the second edition of De cive. ${ }^{68}$ There, Hobbes explained that by 'true reasoning' he meant 'reasoning which

64 De cive, chap. I, § 9. On the Citizen, 27-28.

65 De cive, chap. I, § 10. On the Citizen, 28.

$66 J N G$ 1672, book II, chap. 2, § 3. LNN, 158-159.

$67 J N G$ 1672, book VII, chap. 1, § 7. LNN, 959-962.

68 Palladini, 'Pufendorf Disciple of Hobbes,' 58. 
draws conclusions from true principles correctly stated', and that 'every violation of natural law consists of false reasoning or in stupidity, when men fail to see what duties toward other men are necessary to their own preservation',69 If read in isolation, this remark could be seen as affirming that there is an intersubjective criterion for personal survival already in the state of nature. However, in the note Hobbes continued by pointing out that the 'principles of right reasoning about such duties are those laid out in Chapter I, articles 2-7.70 And the conclusion he presented in these articles was that in the state of nature human beings are able and willing to hurt each other, wherefore 'the first foundation of natural Right is that each man protects his life and limbs as much as he can'.71 In the above note, Hobbes offered a mere reformulation of the subjective character of contemplating the requirements of self-preservation in the state of nature. What right reason teaches human beings in that state is that they have no criterion for what is necessary for their preservation other than their own reasoning. ${ }^{72}$ There was nothing in Hobbes's remarks Pufendorf could have used to transform them into something he would have found more acceptable. And in JNG 1684 he was ready to admit that Hobbes's formulations may not allow the favourable interpretation he had suggested, and that if this was so, it was up to Hobbes himself to see 'how he can avoid a just criticism. ${ }^{73}$

As Noel Malcolm has pointed out, the peculiar feature of Hobbes's natural law was that, in the state of nature, natural law was a purely self-regarding norm of human behaviour. ${ }^{74}$ Human beings have an obligation to do whatever they believe is the best way to preserve their own lives, and even in the state of nature this may sometimes mean acting in a sociable and peaceable manner towards others. However, in this case they do so only for instrumental reasons, as the best way to preserve their own lives. Their relationship with other human beings is not governed by any idea of shared humanity, which would have

69 De cive, chap. II, § 1, n. 1. On the Citizen, 33-34.

70 Ibid.

71 De cive, chap. I, § 7. On the Citizen, 27.

72 De cive, chap. II, § 1, note. On the Citizen, 33: 'By right reason in men's natural state, I mean not, as many do, an infallible Faculty, but the act of reasoning, that is, a man's own true Reasoning about actions of his which may conduce to his advantage or other men's loss. I say his own reasoning, because [...] outside of a Commonwealth, where no one can distinguish right reason from false except by making comparison with his own, each man's own reason must be regarded not only as the measure of his own actions, which are taken at his own risk, but also as the measure by which to judge the reasoning of others in his affairs'.

$73 J N G$ 1684, book II, chap. 2, § 3. LNN, 159.

74 Noel Malcolm, Aspects of Hobbes (Oxford: Oxford University Press, 2002), 32-34, 444-446. 
moral implications. Human beings and sovereigns sin against natural law, for example, by cruelty, which Hobbes defined as 'vengeance without regard to future good. ${ }^{75}$ However, even the duty to abstain from cruelty follows from the system of self-regarding duties and rights related to self-preservation, not from any duty to respect the humanity of the victim. And what counts as cruelty depends solely on one's own evaluation of what is and what is not necessary for one's preservation. Thus, Hobbes remarked that what is done 'of necessity, or in pursuit of peace, or for self-preservation is done rightly'. All other harm inflicted 'on men is a violation against natural Law and wrong against God.' 76 What he did not say was that such behaviour would be wrong against other people. While the law of nature is a universal moral norm of human behaviour, in the state of nature it is universal only in the sense that it is 'duplicated in every individual'. It does not require 'a person to respect the good of any other human being, still less of humanity in general as a primary good. ${ }^{77}$

The above applied also to interstate relations, in which sovereigns were obligated by natural law to advance the preservation and welfare of their subjects. To be sure, Hobbes made it clear that the state of nature which prevailed between sovereign states differed from the one among independent individuals. Above all, as people living in civil societies were quite well protected, the sovereign had most often no reason for unprovoked aggression towards other states. In fact, Hobbes was mostly critical of wars of aggression and expansion, holding that these have, with great likelihood, negative consequences for the long-term security and prosperity of one's country. ${ }^{78}$ For most of the time, natural law ordered sovereigns to advance peaceful relations and commerce with neighbouring countries. Yet, this was a purely self-regarding code of conduct which did not establish any coherent system of rights and duties among sovereign states. This Hobbes expressed clearly in Dialogue between a Philosopher and a Student of the Common laws of England, written in the 166os but published posthumously in 1681 . There, the philosopher, who represented Hobbes, remarked that the king is entitled to defend militarily a neighbouring country which is under attack if he believes that the invader has plans to assault his own country too. When the lawyer replied that surely the king is entitled to do so only if the attack against the neighbour is unjustified, the philosopher disregarded such questions as irrelevant. The only thing which justifies avoiding interference is that the invader 'will, and can put me in security, that neither

75 De cive, chap. III, § 27, note. On the Citizen, 54.

76 Ibid.

77 Malcolm, Aspects of Hobbes, 444.

78 Malcolm, Aspects of Hobbes, 441. 
he, nor his Successors shall make any Advantage of the Conquest of my Neighbour, to do the same to me in time to come.79 In Dialogue the philosopher also identified 'the necessity of subsisting' as a just reason for occupying new territories. If the subjects of the sovereign are facing starvation, he is entitled to invade a neighbouring country with more fertile land, irrespective of the consequences this may have for its inhabitants. ${ }^{80}$ In Leviathan Hobbes stated that if the number of poor people exceeds what the country can sustain, some of them should be 'transplanted into Countries not sufficiently inhabited'. And even though the people moving to colonies should not 'exterminate those they find there', but only 'constrain them to inhabit closer together', there was no reason to consider what the original inhabitants might think about the matter. ${ }^{81}$

Pufendorf addressed the self-regarding element in Hobbes's natural law when he criticized the latter's infamous claim that the natural state of human beings is war. On this issue, Pufendorf was not so much concerned about the universal condition of war Hobbes had attributed to the fictive condition of independent individuals. ${ }^{82}$ What he found truly objectionable was Hobbes's claim that the condition between commonwealths is a 'state of hostility', so that even 'when the fighting between them stops, it should not be called Peace, but an intermission during which each watches the motion and aspect of its enemy and gauges its security not on the basis of agreements but by the strength and designs of the adversary'. ${ }^{83}$ Pufendorf's reason for rejecting such a statement was not an assumption that in reality relations between human beings or states would be overwhelmingly peaceful in character. He held it evident that the condition which once prevailed between independent male householders had been saturated by fear of aggression, and that this had been the main reason for the establishment of civil societies. ${ }^{84}$ War was constantly present also in interstate relations, and there was no reason to assume that things would be different one day.

For Pufendorf, the main question regarding the state of nature was not the amount of warfare that takes place among sovereign states. The crucial

79 Thomas Hobbes, Writings on the Common Law and Hereditary Right, ed. Alan Cromartie and Quentin Skinner (Oxford: Oxford University Press, 2005), 23. Malcolm, Aspects of Hobbes, 455-456.

8o Hobbes, Writings on the Common Law, 135 .

81 Thomas Hobbes, Leviathan, ed. Richard Tuck (Cambridge: Cambridge University Press, 1991), 239 .

$82 J N G$ 1672, book II, chap. 2, § 7. LNN, 168-169.

83 De cive, chap. XIII, § 7. On the Citizen, 144-145.JNG 1672, book II, chap. 2, § 5. LNN, 165 .

84 JNG 1672, book VII, chap. 1, § 7.LNN, 961 . 
question was, rather, the moral relation which prevails between them. Hobbes had written that when human beings 'are not subject one to the other or to any common ruler', they are 'enemies [hostes] to each other'. ${ }^{85}$ Pufendorf saw this as a statement concerning the moral relations between states. In the chapter on the laws of war, he explained that when someone is my enemy, this means that I am morally allowed 'to use force against him to any degree, or so far as I may think desirable' (in infinitum, aut quantum mihivideatur). ${ }^{86}$ In the case of an enemy, one is always entitled to execute a pre-emptive strike. Of course, the logic of Pufendorf's argument allowed the sovereign sometimes to decide that it would be wiser to abstain from such attacks, and to uphold the condition of ceasefire with the enemy. However, he should do so only for instrumental reasons, which have to do with the preservation and welfare of his own people. If he chooses to do otherwise, he does nothing wrong to his enemy.

In other words, if we assume that the natural condition of human beings is war, we are forced to conclude that relations between states are governed by self-regarding principles of self-interest and security. Therefore, Pufendorf held that it is a matter of the utmost importance to know whether those who have no common master, and neither obey nor command one another, should be considered as mutual enemies, or as peaceable people and friends. ${ }^{87}$ And he strongly argued that even though war is, due to human nature, an inescapable element of the human condition, it should always be seen as an aberration from the natural human condition, which is that of peace. In saying this, Pufendorf was not using the term 'peace' in the same way he did in the chapter on moral entities, where he defined peace as a 'state in which men dwell together in quiet and without violent injuries, and render their mutual dues, as of obligation and desire. 88 The peace which prevails in the state of nature does not refer to a total absence of aggression and warfare, but to the moral duty to uphold peace as much as one can. Peace is the state 'the creation and preservation of which constitutes one of the chief reasons for the law of nature being placed in the hearts of men'.89 The reciprocal duty to cultivate peaceful sociality prevails not only within civil society but also in the state of nature, imposing duties to abstain from harming those who do not harm me, to allow everyone to enjoy their own possessions, and to fulfil the agreements they have made

\footnotetext{
85 De cive, chap. XIV, § 19. On the Citizen, 164.

$86 J N G$ 1672, book VIII, chap. 6, § 7. LNN, 1298.

87 JNG 1672, book II, chap. 2, §5. LNN, 165 .

$88 J N G$ 1672, book I chap. 1, § 8. LNN, 9 .

89 JNG 1672, book VIII, chap. 6, § 2. LNN, 1292.
} 
with one another..$^{90} \mathrm{Of}$ course, there is no reason to assume that people or sovereigns always obey these obligations. Nevertheless, the 'maintenance of peace toward all men as such is a natural state of man' in the sense that it rests 'upon that obligation of natural law, by which all men are bound, in so far as they are endowed with reason, and which does not owe its original introduction to any convention of men.' ${ }^{91}$ All this was not contradicted when Pufendorf remarked that the peace which prevails in the state of nature is but a weak and untrustworthy thing. ${ }^{92}$ This merely indicated that it is the duty of the sovereign not only to cultivate peace and friendship with neighbouring countries, but also to take 'care that everything required to repel invasion stands in readiness, such as forts, arms, and troops. ${ }^{93}$

Pufendorf referred to the self-regarding element in Hobbes's theory also when in $J N G 1684$ he defended the general duty of friendship against Hobbes. While God has so adapted natural law with human nature that its observance is always 'connected with profit and advantage of men', in justifying the duty of friendship as a command of natural law one should not refer to these advantages but to the common nature of human beings. If, for example, one gives a reason for not injuring another person, one does not point out that such behaviour is advantageous for oneself, though it evidently is. What one says is that the other person is 'an animal related by nature, whom it is a crime to injure. ${ }^{94}$ Behind such reasoning one can detect the idea that if the justification for natural law is that obeying it is useful for myself, then if I fail to observe it, the only person to whom I do something wrong is myself. For Pufendorf, the idea of natural law as a norm God has imposed to advance the salus of the whole humankind enabled one to escape such a counterintuitive conclusion.

Pufendorf's non-Hobbesian understanding of the state of nature was reflected in his account of interstate relations. As mentioned above, in Hobbes's view, a sovereign contemplating the need to assist a neighbouring country against an invading third party had no reason to assess the moral character of the war. Pufendorf agreed that wars may sometimes be fought on behalf

$90 \quad J N G$ 1672, book II, chap. 2, § 9. $L N N, 118$. In JNG 1684 Pufendorf added the duty to advance the interests of others, in so far as one is not bound by more pressing obligations.

$91 J N G$ 1672, book II, chap. 2, § 11. LNN, 175 .

$92 J N G$ 1672, book II, chap. 2, § 12. LNN, 176.

$93 J N G 1672$, book VII, chap. 9, § 13. $L N N, 1126$. The general duty to cultivate peace does not forbid civil sovereigns to establish various 'systems of states' with those with whom they have common interests. See Michael Seidler, "Monstrous" Pufendorf: Sovereignty and System in the Dissertations,' in Monarchism and Absolutism in Early Modern Europe, ed. Cesare Cuttica and Glen Burgess (London: Pickering \& Chatto, 2011), 170-174. 
of a neighbouring country. Yet, while the issue was complicated, and there were several things the sovereign had to consider carefully, what was clear was that the war must be morally justified. ${ }^{95}$ Pufendorf also departed from the Hobbesian view that to prevent his citizens from starving, the sovereign was entitled to disregard the loss of lives conquering new territories would cause to their original population. Of course, he admitted that there is a right of necessity which entitles people facing starvation through no fault of their own to disregard conventional property rights, if no other way of being nourished is available to them. And in the state of natural liberty, food can be taken from its owners even by means of war. However, such a right applies only when the owners have more than they need for themselves. It never justifies taking food when the result is that the owners become unable to survive. ${ }^{96}$ Pufendorf did not present necessity as a legitimate reason for conquering territories belonging to other nations. Nor did he find acceptable the idea of transplanting the surplus population to colonies without asking the opinion of those who already lived there. His argument against Vitoria's and Grotius's justifications for colonialism relied on the idea that Europeans and the inhabitants of colonialized countries share reciprocal duties and rights. When he added that the native people were entitled to possess unoccupied land in the form of collective ownership, it followed that the duties of hospitality did not dismantle their right to decide on the use of their own territories any more than it did in the case of Europeans. When Europeans failed to acknowledge these rights, they violated what Pufendorf described as the most universal and necessary of all the duties of natural law: the duty not to hurt other human beings. ${ }^{97}$

To cite Noel Malcom one more time, with his account of natural law Hobbes departed radically from the Stoic and scholastic versions of natural law by taking 'no cognizance of the good of mankind as such'. While individuals and sovereigns had rights and duties in the state of nature, due to the self-regarding character of natural law these were not 'fixed by nature in any pattern of mutual

$95 J N G$ 1672, book VIII, chap. 6, § 14. LNN, 1305.

96 JNG 1672, book II, chap. 6, § 5. LNN, 301-302.

$97 J N G$ 1672, book III, chap. 1, § 1; book III, chap. 3, §§ 7-10; book IV, chap. 6, § 4. LNN, 313-314, 359-368, 571. On Pufendorf's critique of colonialism, see Barbara Arneil, John Locke and America. The Defence of English Colonialism (Oxford: Clarendon Press, 1996), 54-6o; See also Christov, Before Anarchy, 200-297. This analysis does not, in my view, confirm the author's claim about the Hobbesian character of Pufendorf's international theory. For the claim that, in Pufendorf's view, Spanish colonialism took place 'in the a-licit state of nature', see Ian Hunter, 'The Figure of Man and the Territorialisation of Justice,' Intellectual History Review 23 (2013): 296-297. 
harmony or reciprocity'. Outside civil society, natural rights and natural duties were often in direct conflict. It was only inside the commonwealth that they could 'be presumed to be in harmony' ${ }^{98}$ Pufendorf followed Hobbes in rejecting the metaphysical assumptions and teleological conceptions of the Stoic and scholastic doctrines, and by adopting an Epicurean-style anthropology. ${ }^{99}$ One thing Pufendorf was not ready to share with Hobbes, however, was the idea of natural law as a self-regarding rule concerning the preservation of one's own life. Instead, he established natural law on a highly constricted notion of God's intentions, which, he thought, should be acceptable to all human beings, irrespective of their religious confession. This enabled Pufendorf to hold that humankind was one moral community, whose members had duties to one another simply due to their shared humanity. The duties and rights which prevailed in the state of nature were perhaps not always as neatly organized as those in civil society, but Pufendorf held it evident that while the main duty of civil sovereigns was to advance the safety and welfare of their country, natural law imposed on them genuine moral duties to other states and their inhabitants. When sovereigns violated these precepts, they did not merely jeopardize the long-term security and welfare of their country. They also did something morally wrong to their fellow human beings. ${ }^{100}$

\section{Bibliography}

Arneil, Barbara, John Locke and America. The Defence of English Colonialism (Oxford: Clarendon Press, 1996).

Christov, Theodore, Before Anarchy. Hobbes and His Critics in Modern International Thought (Cambridge: Cambridge University Press, 2015).

Fiorillo, Vanda, 'States, as Ethico-Political Subjects of International Law: The Relationship between Theory and Practice in the International Politics of Samuel Pufendorf,' in System, Order, and International Law: The Early History of International Legal Thought from Machiavelli to Hegel, ed. Stefan Kadelbach, Thomas Kleinlein, and David Roth-Isigkeit (Oxford: Oxford University Press, 2017), 199-215.

Haara, Heikki, Sociability in Samuel Pufendorf's Natural Law Theory (PhD diss., University of Helsinki, 2017).

98 Malcolm, Aspects of Hobbes, 455-456.

99 For a celebration of these aspects in Pufendorf's theory, see Ian Hunter, Rival Enlightenments: Civil and Metaphysical Philosophy in Early Modern Germany (Cambridge: Cambridge University Press, 2001).

100 I am grateful to Heikki Haara for commenting on an earlier version of this chapter. 
Hobbes, Thomas, Leviathan, ed. Richard Tuck (Cambridge: Cambridge University Press, 1991).

Hobbes, Thomas, On the Citizen, ed. Richard Tuck, transl. Michael Silverthorne (Cambridge: Cambridge University Press. 1998).

Hobbes, Thomas, Writings on the Common Law and Hereditary Right, ed. Alan Cromartie and Quentin Skinner (Oxford: Oxford University Press, 2005).

Holland, Ben, The Moral Person of the State. Pufendorf. Sovereignty, and Composite Polities (Cambridge: Cambridge University Press, 2017).

Hont, Istvan, 'The Language of Sociability and Commerce: Samuel Pufendorf and the Theoretical Foundations of the "Four-Stages" Theory,' in The Language of Political Theory in Early-Modern Europe, ed. Anthony Pagden (Cambridge: Cambridge University Press, 1987), 253-276.

Hunter, Ian, Rival Enlightenments: Civil and Metaphysical Philosophy in Early Modern Germany (Cambridge: Cambridge University Press, 2001).

Hunter, Ian, 'Natural Law as Political Philosophy,' in The Oxford Handbook of Philosophy in Early Modern Europe, ed. Desmond Clarke and Catherine Wilson (Oxford: Oxford University Press, 2011), 475-499.

Hunter, Ian, 'The Figure of Man and the Territorialisation of Justice,' Intellectual History Review, 23 (2013): 289-307.

Malcolm, Noel, Aspects of Hobbes (Oxford: Oxford University Press, 2002).

Palladini, Fiammetta, Samuel Pufendorf dicepolo di Hobbes: Per una reinterpretazione del giusnaturalismo moderno (Bologna: Il Mulino, 199o).

Palladini, Fiammetta, Discussioni seicentesche su Samuel Pufendorf. Scritti Latini: 16631700 (Bologna: Il Mulino, 1978).

Palladini, Fiammetta, 'Pufendorf Disciple of Hobbes: The Nature of Man and the State of Nature: The Doctrine of socialitas,' History of European Ideas, 34 (2008): 26-6o.

Pufendorf, Samuel, Gesammelte Werke, ed. Wilhelm Schmidt-Biggemann, 9 vols. (Berlin: Akademie Verlag / De Gruyter, 1996-2004).

Pufendorf, Samuel, De jure naturae et gentium libri octo, 2 vols., vol. 2: Of the Law of Nature and Nations, transl. C.H. Oldfather and W.A. Oldfather, The Classics of International Law, ed. J.B. Scott, no. 17 (Oxford: Clarendon Press, 1934).

Pufendorf, Samuel, On the Duty of Man Citizen, ed. James Tully, transl. Michael Silverthorne (Cambridge: Cambridge University Press, 1991).

Pufendorf, Samuel, The Political Writings of Samuel Pufendorf, transl. Michael J. Seidler, ed. Craig L. Carr (New York: Oxford University Press, 1994).

Saastamoinen, Kari, The Morality of the Fallen Man. Samuel Pufendorf on Natural Law (Helsinki: Finnish Historical Society, 1995).

Saastamoinen, Kari, 'Liberty and Natural Rights in Pufendorf's Natural Law Theory,' in Transformations in Medieval and Early-Modern Rights Discourse, ed. Virpi Mäkinen and Petter Korkman (Dordrecht: Springer, 2006), 225-255. 
Saastamoinen, Kari, 'Pufendorf on Natural Equality, Human Dignity, and Self-Esteem,' Journal of the History of Ideas 1 (2010): 39-62.

Seidler, Michael, '“Monstrous" Pufendorf: Sovereignty and System in the Dissertations,' in Monarchism and Absolutism in Early Modern Europe, eds. Cesare Cuttica and Glen Burgess (London: Pickering \& Chatto, 2011), 159-175.

Seidler, Michael, 'Pufendorf's Moral and Political Philosophy,' The Stanford Encyclopedia of Philosophy (Winter 2015 Edition), ed. Edward N. Zalta, https://plato.stanford .edu/archives/win2015/entries/pufendorf-moral/.

Schröder, Peter, Trust in Early Modern International Political Thought, 1598-1713 (Cambridge: Cambridge University Press, 2017).

Tuck, Richard, 'The “Modern” Theory of Natural Law,' in The Languages of Political Theory in Early-Modern Europe, ed. Anthony Pagden (Cambridge: Cambridge University Press, 1987), 99-119.

Tuck, Richard, The Rights of War and Peace. Political Thought and the International Order from Grotius to Kant (Oxford: Oxford University Press, 1999). 